\title{
An Examination of the Relationship of Corporate Governance to Firm Performance: Empirical Evidence from Vietnamese Listed Companies
}

\author{
Nguyen Ngoc Dieu Le ${ }^{1} \&$ Nguyen Ngoc Dieu Thi ${ }^{1}$ \\ ${ }^{1}$ Foreign Trade University, Ho Chi Minh City Campus, Ho Chi Minh City, Vietnam \\ Correspondence: Nguyen Ngoc Dieu Le, Foreign Trade University, Ho Chi Minh City Campus, \#15D5, Ward 25, \\ Binh Thanh District, Ho Chi Minh City, Vietnam.
}

Received: June 21, 2016

Accepted: July 11, 2016

Online Published: July 18, 2016

doi:10.5430/ijfr.v7n4p190

URL: http://dx.doi.org/10.5430/ijfr.v7n4p190

\begin{abstract}
With a sample of Vietnamese listed firms, we examine the relationship between performance and the corporate governance in the context of an emerging country. While board size, chairman ownership, foreign ownership and ownership concentration positively relates with firm's performance as measured by Tobin's Q, foreign ownership appears to have the strongest effect on firm performance. Besides, we observe that highly levered firms perform worse. The hypotheses that duality and CEO ownership significantly affects firm performance are statistically rejected.
\end{abstract}

Keywords: corporate governance, board size, chairman ownership, foreign ownership, ownership concentration

\section{Introduction}

Corporate governance has become a state-of-the-art topic in finance and management. This concept refers to the system of principles, policies, procedures and clearly defined responsibilities and accountabilities used by stakeholders to (1) eliminate or reduce conflicts of interest and (2) assure the use the company's assets in a manner consistent with the best interests of stakeholders. The effects of corporate governance on firm performance have been given light by plenty of theoretical and empirical researches. Jensen and Meckling (1976) indicate the positive relationship between management ownership and performance of the firm. In all the components of corporate governance, Demsetz and Villalonga (2001) assert that the ownership structure is an important factor driving profitability and risk of the company. Berle and Means (1932) argue that ownership divergence undermine firm value. Most of the presented evidence has focused on either the Anglo-American context, or other developed countries (Elsayed et al., 2011). In fact, more studies in developing countries are in need for a better understanding of the dynamics of corporate mechanisms and structures, because it is irrational to generalize conclusions from prior studies on other firms that operate in different legal or cultural environments (Eisenberg et al. 1998: 36).

Moreover, the quality of corporate governance in Vietnam has declined since 2010, according to the Vietnam Corporate Governance Scorecard Report by International Finance Corporation (World Bank). Given the importance of corporate governance and the capital demand for national reform, the country must improve corporate governance practice in order to raise confidence of domestic and foreign investors.

Inspired by the current situation, this study is designed to add to existing literature with more insight into the effect of corporate governance in Vietnam as an emerging country. Specifically, it explores the effect of the board of directors and ownership structure on value creation using a sample of Vietnam's listed firms. The study consists of five parts. The following section presents a summary of the studies investigating the relationship between corporate governance and corporate performance. In Section 3 the econometric methodology and model structure are presented. Section 4 covers the results of the econometric models. The last part concludes the study with general remarks.

\section{Literature Review}

Many studies have investigated the relationship between firm performance and corporate governance. Generally, there are three groups of measures dominating the relevant literature to reflect corporate performance. The first group consists of traditional accounting-based measures such as return on assets (Himmelberg et al., 1999), return on equity (Bhagat et al., 1999). The second group includes market-based measures, such as Tobin's Q (Bhagat et al 2008) or stock return (Mitton, 2002). In addition, as "value maximization" is the eventual objective of corporations, 
value-based measures are used to reflect corporate performance, dominantly economic value added (EVA), market value added (MVA) and cash value added (CVA) (Lehn and Makhija 1996; Bayrakdaroglu et al, 2012).

Out of measures in relation to corporate governance, board size has occupied a substantial number of studies in literature. The board is said to be the central player in mitigating possible conflicts between managers and shareholders (Guest, 2008). However, whether a large or a small board fertilizes corporate governance is still a controversial topic among scholars. Pfeffer and Salancik (1978) suggest that the larger board improves effectiveness of external linkage. Dalton (1999) argues that large-sized board positively affects corporate performance by enhancing the firm's ability to build outer relationships, increasing information quality and avoiding resource rarity. Whereas, Lehn el at (2003) reveals that the firm's information-sharing and decision-making process can be more efficient with expanded board. Recent researches also offer empirical evidence to confirm positive influence of large board size on corporate performance (Bozec and Dia 2007; Belkhir, 2009).

On the other hand, defenders of small board size remain a skeptic view. Lipton and Lorsch (1992) and Jensen (1993) criticize performance of large boards. In details, problems of board expansion are (1) limitation in fulfilling the board's main functions, (2) lack of coherence and (3) special difficulties in communication and coordination among management layers. Yermack (1996) confirms that these may result in higher risk of free-rider trouble, increase the cost of information sharing and exacerbate principal-agency problem. Moreover, the large board size also impairs efficiency of idea generation and dispersion (Ahmed et al. 2006). Many papers advocate positive impacts of small boards on corporate performance (Bohren and Odegaard 2001; Postma et al. 2003; De Andres et al. 2005).

However, relationship between board size and corporate governance is not recognized by all scholars. While Kaymak and Bektas (2008) reject the relationship, Bennedsen (2004) provides that this relationship is unnecessary to be linear. Especially, the outcome likely varies in correspondence with different performance measures (Loderer and Peyer 2002), research methodology (Maka and Kusnadi 2005), corporate scope and type (Di Pietra et al. 2008). In other words, an assumption that there is one size fitting all corporations or that the right choice must be a large board or small one is impracticable. Board size per se cannot drive corporate governance and that inherent characteristics of the board of directors may also decide effectiveness of the board rather than the number of the board's members only (Aguilera and Jackson 2003; Aguilera 2005).

Besides, ownership structure is another factor deciding effectiveness of corporate governance practices. Accordingly, ownership concentration is a potential but controversial explanation for mixed finding of above researches. This concept refers to the proportion of total ownership of people or institutions with more than a specific percentage of shares to the total capital of the firm. Berle and Means (1932) argue that the more diffusing a firm's ownership becomes, the more discretely managers act in manners that unnecessarily complies with the highest interest of the shareholders. In other words, they support positive relationship between ownership concentration and firm performance. Citak (2007) confirms parallel movement between ownership concentration and market-to-book value ratio.

However, the above approach has failed to convince all scholars. Yurtoglu's evidence (2000) reveals at least two drawbacks of concentrated ownership. Accordingly, high ownership concentration may limit diversification possibilities and liquidity. Moreover, a pyramid structure exposes big owners to high temptation of trading off benefits of small shareholders and the firm as a whole with interests of the group only (Yurtoglu, 2000). Yet, Demsetz and Villalonga (2001) deny any significant connection between a firm's ownership concentration and its performance.

Managerial ownership is another factor attracting scholars' concern. According to Jensen and Meckling (1976), managers will better protect interests of shareholders if they are a part of them. Thus, manager ownership is believed to stimulate corporate performance (Hiraki, 2003). Although it cannot deny positive role of managerial ownership in mitigating agency problems, Himmelberg (1999) argues that low management ownership may be the optimal remuneration arrangement for the firm with low level of the moral hazard problem. Therefore, the relationship between managerial ownership and corporate governance should be interpreted case by case.

Last but not least, in the context of globalization, foreign ownership is another factor with increasing importance, especially in emerging countries. Aydin et al. (2007) revealed that foreign-owned firms performed better than domestically-owned firms based on ROA measure. High proportion of foreign equity is associated with firms' significant economies of scale, capital intensity, dynamic growth rate, know-how management and qualified human resource (Taymaz and Ozler, 2007). This result is deemed as an evidence of the positive impacts of foreign ownership on corporate performance. 


\section{The Model}

The main dependent variable of this paper is Tobin's Q ratio, which is widely used to reflect firm performance. This ratio refers to the proportion of the firm market value to the replacement cost of its assets. According to Chung and Pruitt (1994), Tobin's Q ratio is approximately measured as follow:

$$
\mathrm{Q}=[\mathrm{MV}(\mathrm{CS})+\mathrm{BV}(\mathrm{PS})+\mathrm{BV}(\mathrm{LTD})+\mathrm{BV}(\mathrm{INV})+\mathrm{BV}(\mathrm{CL})-\mathrm{BV}(\mathrm{CA})] / \mathrm{BV}(\mathrm{TA})
$$

MV (CS): the market value of the common stocks; BV: the book value

PS: the preferred stocks;

INV: the inventory;

CA: the current assets
LTD: the firm long-term debt;

CL: the current liabilities;

TA: the total assets

In short, the Tobin's Q ratio is calculated as the market value of a company divided by the replacement value of its assets. Thus, Tobin's Q is argued to capture a firm's ability of attracting investment and creating value. In details, a firm will be more attractive to investors if its Tobin's $Q$ is greater than one. On the other hand, if the ratio falls below one, this indicates a low incentive for investors to invest in the firm (Kim et al. 1993). Therefore, Tobin's q (Q) acts as an indicator of firm performance in this paper.

Moreover, the study utilizes many explanatory variables in relation to corporate governance. The study employs many explanatory variables to reflect corporate governance. In details, board size is the main explanatory variable in this research. It is exemplified by the number of member if the board director and reflects the scope of the board (Wen et al. 2002; Kim 2005). Besides, inspired by previous work, some other independent variables exhibiting ownership structure are used as proxies of corporate governance. It is worthy to note that many Vietnamese companies are held by relatively few shareholders due to the first stage of industrialization and modernization. Moreover, Vietnam's economic liberalization has increased foreign ownership and been expected to improve domestic firms in recent years. Thus, ownership concentration and foreign ownership are employed as explanatory variables in the analysis models. Especially, the paper uses chairman ownership as another proxy of corporate governance. It is argued that the board of directors plays a central role in a firm's inner governance mechanism. Thus, as the leader of the board of directors, the more shares the chairman holds, the more he may focus on corporate governance.

Lastly, leverage is also utilized as a control variable in this study. A firm's leverage is calculated by the ratio of total assets over total equity. Its potential impact on firm performance is undetermined. On the one hand, debt may limit a firm's liquidity and investment (Shleifer \& Vishny, 1992) and increase financial distress cost to the detriment of firm value (De Angelo and Masulis, 1980). On the other hand, debt may not only restrict the cash flow available for managers' discretion and urge them to take value-maximizing plan into account (Jensen, 1986; Stulz, 1990) but also create the benefit of tax shield. Therefore, the stronger effect of these will decide the net influence of leverage on firm performance.

Variables and predictions are expressed in Table 1.

Table 1. Explanatory variables and control variables used in the study

\begin{tabular}{llllll}
\hline $\begin{array}{l}\text { Dependent } \\
\text { variable }\end{array}$ & Tobin's Q ratio & $\begin{array}{l}\text { Total market value of firm/ } \\
\text { total asset value }\end{array}$ & TOBINQ & \\
\hline $\begin{array}{l}\text { Explanatory } \\
\text { variables }\end{array}$ & Board size & $\begin{array}{l}\text { The number of members of } \\
\text { the board director }\end{array}$ & BOARDSIZE & $\begin{array}{l}\text { Positive/Neg } \\
\text { ative }\end{array}$ & Positive \\
\hline & $\begin{array}{l}\text { Chairman } \\
\text { ownership }\end{array}$ & $\begin{array}{l}\text { The percentage of equity } \\
\text { owned by the chairman }\end{array}$ & CMANOWN & Positive \\
& $\begin{array}{l}\text { Foreign } \\
\text { ownership }\end{array}$ & $\begin{array}{l}\text { The proportion of foreign } \\
\text { ownership }\end{array}$ & FOREIOWN & & Positive/Neg \\
& $\begin{array}{l}\text { Ownership } \\
\text { concentration }\end{array}$ & $\begin{array}{l}\text { Total ownership of people } \\
\text { or institutions with more } \\
\text { than } 5 \% \text { of shares. }\end{array}$ & BIGOWN & & ative \\
\hline $\begin{array}{l}\text { Control } \\
\text { variables }\end{array}$ & Leverage & Total assets/total equity & LEVERAGE & Positive/Neg & ative \\
\hline
\end{tabular}


The study employs OLS regression to test the relationship among variables in the following equation.

$$
\text { TOBINQ }_{i}=\alpha_{0}+\alpha_{1} \text { BOARDSIZE }_{i}+\alpha_{2} \text { CMANOWN }_{i}+\alpha_{3} \text { FOREIOWN }_{i}+\alpha_{4} \text { BIGOWN }_{i}+\alpha_{5} \text { LEVERAGE }_{i}+\varepsilon_{i}
$$

In another attempt from whose results are not presented here, we have incorporated other factors, either governance related (CEO ownership, duality) or controlling (size, state ownership) into the model, but failed to find any significant relationship between these variables and performance.

\section{Empirical Results}

\subsection{Descriptive Statistics and Preliminary Analysis}

The sample comprises of 1967 observations and covers 575 companies over the period 2007-2012. Financial firms are excluded. Data set is provided collected from Hochiminh Stock Exchange and Hanoi Stock Exchange. Table 2 provides basic statistics for variables used in this paper.

Table 2. Descriptive statistics

\begin{tabular}{|c|c|c|c|c|c|c|}
\hline \multirow[b]{2}{*}{ Variable } & \multicolumn{3}{|c|}{2007} & \multicolumn{3}{|c|}{ 2008-2012 } \\
\hline & Observations & Mean & $\begin{array}{l}\text { Standard } \\
\text { Deviation }\end{array}$ & Observations & Mean & $\begin{array}{l}\text { Standard } \\
\text { Deviation }\end{array}$ \\
\hline TOBINQ & 126 & 2.049 & 1.560 & 1811 & 0.614 & 0.513 \\
\hline BOARDSIZE & & 5.579 & 1.359 & & 5.481 & 1.102 \\
\hline CMANOWN & & 0.174 & 0.184 & & 0.176 & 0.167 \\
\hline BIGOWN & & 0.483 & 0.174 & & 0.475 & 0.184 \\
\hline FOREIOWN & & 0.101 & 0.148 & & 0.073 & 0.116 \\
\hline LEVERAGE & & 2.476 & 1.409 & & 2.836 & 2.460 \\
\hline
\end{tabular}

Clearly, there are significant differences in statistics for variables TOBINQ, FOREIOWN and LEVERAGE in two periods. First of all, mean of TOBINQ falls from 2.051 before 2008 down to 0.61434 after 2008. It may be explained by downturn of Vietnam's financial market since 2008. At the end of December 2007, VN-Index (the market stock index in Vietnam) was around 920, but quickly fell to below 300 at the end of 2008. Accordingly, Vietnam's firms tended to perform in the market upturn twice better than in its downturn in term of Tobin' Q measurement. Simultaneously, the mean of foreign ownership is found to gradually decrease from $10 \%$ in the first period to approximately 7\% in the second one, suggesting withdrawal of foreign capital since the market downturn in 2008. Detailed statistics have shown that foreign ownership has gradually increased again since 2010, yet it is still below pre-crisis level. Moreover, Table 2 reveals a significant increase in the mean of leverage ratio and a sharp upward trend in the standard deviation of this variable over two periods. It shows that the firms have been likely to get more debts and greater dispersion in their financial capacities has been also disclosed in the financial depress. In short, there are significant changes in both firm performance and corporate governance factor in Vietnam's listed companies since the market downturn in 2008. As a consequence, this paper supplements a dummy variable named D to the model in order to reflect impact of the market fluctuation of firm performance. In details, if an observation is recorded before 2008, D is equal to zero. Otherwise, D is equal to 1 . Thus, the model is now amended as follows.

$$
\begin{gathered}
\text { TOBINQ }_{i}=\alpha_{0}+\alpha_{1} \text { BOARDSIZE }_{i}+\alpha_{2} \text { CMANOWN }_{i}+\alpha_{3} \text { BIGOWN }_{i}+\alpha_{4} \text { FOREIOWN }_{i}+\alpha_{5} \text { LEVERAGE }_{i}+\alpha_{6} D_{i} \\
+\varepsilon_{i}
\end{gathered}
$$

\subsection{Regression Result}

The regression result is revealed in Table 3 as follows. 
Table 3. Regression results

\begin{tabular}{|c|c|c|c|}
\hline \multirow{2}{*}{$\begin{array}{l}\text { Dependent variable: } \\
\text { Independent variable }\end{array}$} & \multicolumn{2}{|c|}{ Tobin’ Q } & \multirow[b]{2}{*}{ t-Statistic } \\
\hline & & Coefficient & \\
\hline CONSTANT & $\left(\alpha_{0}\right)$ & $1.686^{* * *}$ & 16.74 \\
\hline BOARDSIZE & $\left(\alpha_{1}\right)$ & $0.025^{*}$ & 1.92 \\
\hline CMANOWN & $\left(\alpha_{2}\right)$ & $0.325 * * *$ & 3.65 \\
\hline BIGOWN & $\left(\alpha_{3}\right)$ & $0.285 * * *$ & 3.46 \\
\hline FOREIOWN & $\left(\alpha_{4}\right)$ & $0.594 * * *$ & 4.70 \\
\hline LEVERAGE & $\left(\alpha_{5}\right)$ & $-0.013 * *$ & -2.14 \\
\hline $\mathrm{D}$ & $\left(\alpha_{6}\right)$ & $-1.409 * * *$ & -24.5 \\
\hline
\end{tabular}

Number of observation: 1937; adjusted $\mathrm{R}^{2}$ (\%): 26.5; F-statistic: 117.33 (p-value: 0.0000)

$$
\begin{aligned}
& \text { TOBINQ }_{i}=\alpha_{0}+\alpha_{1} \text { BOARDSIZE }_{i}+\alpha_{2} \text { CMANOWN }_{i}+\alpha_{3} \text { BIGOWN }_{i}+\alpha_{4} \text { FOREIOWN }_{i}+\alpha_{5} \text { LEVERAGE }_{i}+\alpha_{6} D \\
& +\varepsilon_{i} \\
& { }^{*} \mathrm{p}<0.1 ; * * \mathrm{p}<0.05 ; * * * \mathrm{p}<0.001
\end{aligned}
$$

According to Table 3, if there is one more member in the board, the Tobin's Q will increase by $2.5 \%$. Moreover, boards of directors in Vietnam have approximately 6 on average. Thus, it can be seen that the small board size has currently facilitated firm performance. This finding consists with those of Bohren and Odegaard 2001; Postma et al. 2003; De Andres et al. 2005. Accordingly, board size positively influences on Vietnam's firm performance.

Besides, Table 3 also reveals the variable CMANOWN has statistically significant and positive relationship with TOBINQ. In other words, CMANOWN is found to affect corporate performance positively. Specifically, Tobin's Q increases by $3.25 \%$ on average given $10 \%$ increase in chairman ownership. These findings are consistent with Jensen and Meckling (1976). Therefore, chairman ownership can be thought to affect corporate performance in a positive way.

Moreover, viewing the connection between corporate governance and firm performance from the perspective of foreign ownership, the expectation that foreign ownership will positively affect corporate performance is realized. Out of three independent variables that reflect ownership structure, foreign ownership appears to impose the most important influence on firm performance. High proportions of foreign equity is associated with firms' significant economies of scale, capital intensity, dynamic growth rate, know-how management and qualified human resource (Taymaz and Ozler, 2007).

In addition, Table 3 shows the variable BIGOWN, representing ownership concentration, has statistically significant and positive relationships with TOBINQ. In other words, the proportion of total ownership of people or institutions with more than a $5 \%$ share of the total capital of the firm is significantly related to performance of Vietnamese firms. This result is consistent with Berle and Means (1932). And, Citak (2007) and Baek et al. (2004) also confirm positive relationships of ownership concentration with market-to-book value and Tobin's Q. However, this result is contradict to Yurtoglu (2000), who concludes that ownership concentration has a negative effect on corporate performance, and Demsetz and Lehn (1985), who find no significant relationship between ownership concentration and firm profitability.

Lastly, as a control variable used in this study, LEVERAGE displays a negative and significant (at $1 \%$ level) relationship with Tobin's q ratio. This means that as the weights of debt in the capital structures of companies under analyses increase, firms will experience worse performance. This finding is consistent with that of Adjaoud et al. (2007). However, authors like Black et al. (2003) and Kyereboah-Coleman et al. (2006) argue the existence of a positive and significant relationship between leverage and performance measures. The finding in this seems to reject their claim that companies utilizing a high level of debt might experience high performance.

\section{Conclusion}

The paper uses the data of 575 listed companies, including 1967 observations over the period 2007-2012. Financial firms are excluded in order to examine the relationship between corporate governance and firm performance in Vietnam. Data set is provided collected from Hochiminh Stock Exchange and Hanoi Stock Exchange. The result shows positive influence of board size, chairman ownership, foreign ownership and ownership concentration on performance of Vietnamese listed firms. Among these, foreign ownership seems to have the largest effect. 
The result reveals that performance of Vietnam's listed companies has been facilitated by the small board size. It is argued that when Vietnamese firms have 6 members in their boards on average, the ability of boards of directors to fulfill its main functions will be stipulated. Specifically, as a small group, the board has better group cohesiveness and higher likelihood to take advantages of communication and coordination. Moreover, new ideas and complete opinions will be more easily expressed in the small board, and, thus, the company's monitoring process could be less diffuse. In other words, the current board size may allow Vietnamese listed companies to control free-rider problems, cut information sharing cost, and facilitate the possibility of the CEO controlling the board.

In addition, chairman ownership also has positive contribution to firm performance in Vietnam. Empirical evidence shows that the more shares a chairman holds in a listed company, the more effort he makes to improve the firm's performance and better protect interests of its shareholders. With $17 \%$ on average, chairman ownership acts in positive role in mitigating agency problems in Vietnamese listed companies. However, it is noteworthy that low management ownership may be the optimal remuneration arrangement for the firm with low level of the moral hazard problem (Himmelberg, 1999). Therefore, further research should be done on the relationship between managerial ownership and corporate in the future.

Besides, the paper's result supports positive relationship between level of ownership concentration and firm performance in Vietnam. The ownership concentration is approximately $50 \%$ on average in listed companies, which has currently fertilized firms' performance. It is argue that the less diffusing a firm's ownership becomes, the less discretely managers act in manners that unnecessarily complies with the highest interest of the shareholders. This result is consistent with Citak's findings (2007) that confirm parallel movement between ownership concentration and market-to-book value ratio.

Last but not least, in the context of globalization, foreign ownership is the most important factor influencing Vietnamese listed firms. According to empirical evidence of the research, high proportion of foreign equity is associated with Vietnamese listed firms' significant economies of scale, capital intensity, dynamic growth rate, know-how management and qualified human resource. This result is deemed as an evidence of the positive impacts of foreign ownership on corporate performance. It suggests that Vietnamese listed companies should attract more foreign direct investment to fertilizer their firm performance.

However, there are some limitations in the paper. To date, value-based indicators such as EVA, MVA are becoming more popular as measures of firm's performance. Moreover, other factors of corporate governance, such as management ownership, board composition, board independence, are not considered in this paper. We suggest that more studies should be done using different approaches to confirm or reject the results from our study.

\section{References}

Adjaoud, F., D. Zeghal, \& S. Andaleeb. (2007). The effect of board quality on performance: A study of Canadian firms. Corporate Governance: An International Review, 15, 623-635.

Aguilera, R. (2005). Corporate governance and director accountability: An institutional comparative perspective. British Journal of Management, 16, S39-S54. http://dx.doi.org/10.1111/j.1467-8551.2005.00446.x

Aguilera, R., \& Jackson, G. (2003). The cross-national diversity of corporate governance: Dimensions and determinants. Academy of Management Review, 28, 447-465. http://dx.doi.org/10.5465/AMR.2003.10196772

Ahmed, K., Hossain, M., \& Adams, M. (2006). The effects of board composition and board size on the informativeness of annual accounting earnings. Corporate Governance: An International Review, 14, 418-431. http://dx.doi.org/10.1111/j.1467-8683.2006.00515.x

Aydın, Nurhan, M. Sayım, \& A. Yalama. (2007). Foreign ownership and firm performance: Evidence from Turkey. International Research Journal of Finance and Economics, 11, 103-111.

Baek, J.-S., J.-K. Kang, \& K. S. Park. (2004). Corporate governance and firm value: Evidence from the Korean financial crisis. Journal of Financial Economics, 71, 265-313. http://dx.doi.org/10.1016/S0304-405X(03)00167-3

Bayrakdaroglu, A., Ersoy, E., \& Citak, K. (2012). Is There a Relationship Between Corporate Governance and Value-based Financial Performance Measures? A Study of Turkey as an Emerging Market. Asia-Pacific Journal of Financial Studies, 41(2), 224-239. http://dx.doi.org/10.1111/j.2041-6156.2012.01071.x

Belkhir, M. (2009). Board of directors' size and performance in the banking Industry. International Journal of Managerial Finance, 5(2), 201-221. 
Bennedsen, M., Kongsted, H., \& Nielsen, K. (2004). Board size effects in closely held corporations. Institute of Economics, University of Copenhagen. Working papers, Centre for Applied Microeconometrics. Retrieved from http://www.econ.ku.dk/CAM/

Berle, A. A., \& G. C. Means. (1932). The modern corporation and private property. Macmillan, New York.

Bhagat, S., \& B. Bolton. (2008). Corporate governance and firm performance. Journal of Corporate Finance, 14, 257-273. http://dx.doi.org/10.1016/j.jcorpfin.2008.03.006

Bhagat, S., D. C. Carey, \& C. M. Elson. (1999). Director ownership, corporate performance, and management turnover. Business Lawyer, 54, 885-919.

Black, B. S., H. Jang, \& W. Kim. (2003). Does corporate governance affect firm value? Evidence from Korea. Working Paper No: 237, Stanford Law School, Stanford.

Bohren, O., \& Odegaard, B. (2001). Corporate governance and economic performance: A closer look. Working paper, The Norwegian School of Management.

Bozec, R., \& Dia, M. (2007). Board structure and firm technical efficiency: Evidence from Canadian state-owned enterprises. European Journal of Operations Research, 177, 1734-1750. http://dx.doi.org/10.1016/j.ejor.2005.10.001

Chung, H., \& Pruitt, W. (1994). A simple approximation of Tobin's q. Financial Management, 23, 70-74.

Citak, L. (2007). The impact of ownership structure on company performance: A panel data analysis on Istanbul Stock Exchange listed (ISE-100) companies. International Research Journal of Finance and Economics, 9, 231-245.

Coles, J., Daniel, N., \& Naveen, L. (2008). Boards: Does one size fit all?. Journal of Financial Economics, 87, 329-356. http://dx.doi.org/10.2307/3665623

Dalton, D. R., C. M. Daily, A. E. Ellstrand, \& J. L. Johnson. (1998). Meta-analytic reviews of board composition, leadership structure, and financial performance. Strategic Management Journal, 19, 269-290. http://dx.doi.org/10.1002/(SICI)1097-0266(199803)19:3<269::AID-SMJ950>3.0.CO;2-K

Dalton, D., Daily, C., Johnson, J., \& Ellstrand, A. (1999). Number of directors and financial performance: A meta-analysis. Academy of Management Journal, 42, 674-686. http://dx.doi.org/10.2307/256988

De Andres, P., Azofra, V., \& Lopez, F. (2005). Corporate boards in OECD countries: Size, effectiveness, functioning and effectiveness. Corporate Governance: An International Review, 13, 197-209. http://dx.doi.org/10.1111/j.1467-8683.2005.00418.x

De Angelo, H., \& R. W. Masulis. (1980). Optimal Capital Structure under Corporate and Personal Taxation. Journal of Financial Economics, 8, 3-29. http://dx.doi.org/10.1016/0304-405X(80)90019-7

Demsetz, H., \& B. Villalonga. (2001). Ownership structure and corporate performance. Journal of Corporate Finance, 7, 209-233. http://dx.doi.org/10.1016/S0929-1199(01)00020-7

Demsetz, H., \& K. Lehn. (1985). The structure of corporate ownership: Causes and consequences. Journal of Political Economy, 93, 1155-1177. http://dx.doi.org/10.1086/261354

Di Pietra, R., Grambovas, C., Raonic, V., \& Riccaboni, A. (2008). The effects of board size and 'busy' directors on the market value of Italian companies. Journal of Management and Governance, 12, 73-91. http://dx.doi.org/10.1007/s10997-008-9044-y

Eisenberg, T., Sundgren, S., \& Wells, M. (1998). Larger board size and decreasing firm value in small firms. Journal of Financial Economics, 48, 35-54. http://dx.doi.org/10.1016/S0304-405X(98)00003-8

Elsayed, K. (2011). Board size and corporate performance: the missing role of board leadership structure. Journal of Management \& Governance, 15(3), 415-446. http://dx.doi.org/10.1007/s10997-009-9110-0

Guest, P. (2008). The determinants of board size and composition: Evidence from the UK. Journal of Corporate Finance, 14, 51-72. http://dx.doi.org/10.1016/j.jcorpfin.2008.01.002

Himmelberg, C. P., R. G. Hubbard, \& D. Palia. (1999). Understanding the determinants of managerial ownership and the link between ownership and performance. Journal of Financial Economics, 53, 353-384. http://dx.doi.org/10.1016/S0304-405X(99)00025-2 
Hiraki, T., H. Inoue, A. Ito, F. Kuroki, \& H. Masuda. (2003). Corporate governance and firm value in Japan: Evidence from 1985 to 1998. Pasific-Basin Finance Journal, 11, 239-265. http://dx.doi.org/10.1016/S0927-538X(03)00023-4

Jensen, M. (1993). The modern industrial revolution, exit, and the failure of internal control systems. The Journal of Finance, 48, 831-880. http://dx.doi.org/10.1111/j.1540-6261.1993.tb04022.x

Jensen, M. C. (1986). Agency costs of free cash flow, corporate finance and takeovers. American Economic Review, $76,323-3291$.

Jensen, M. C., \& W. H. Meckling. (1976). Theory of the firm: Managerial behavior, agency costs and ownership structure. Journal of Financial Economics, 3, 305-360. http://dx.doi.org/10.1016/0304-405X(76)90026-X

Kaymak, T., \& Bektas, E. (2008). East meets west? Board characteristics in an emerging market: Evidence from Turkish banks. Corporate Governance: An International Review, 16, 550-561. http://dx.doi.org/10.1111/j.1467-8683.2008.00713.x

Kim, K., Henderson, G., \& Garrison, S. (1993). Examination of Tobin's q for takeover firms. Quarterly Journal of Business and Economics, 32, 3-26.

Kyereboah-Coleman, A., C. K. D. Adjasi, \& J. Abor. (2006). Corporate governance and firm performance: Evidence from Ghanaian listed companies. Corporate Ownership \& Control, 4, Winter 2006-2007, 123-132.

Lehn, K., \& A. K. Makhija. (1996, May/June). EVA and MVA as performance measures and signals for strategic change. Strategy \& Leadership, 24, 34-38.

Lehn, K., Sukesh, P., \& Zhao, M. (2003). Determinants of the size and structure of corporate boards: 1935-2000. Working paper, Katz Graduate School of Business. http://dx.doi.org/10.2139/ssrn.470675

Lipton, M., \& Lorsch, W. (1992). A modest proposal for improved corporate governance. Business Lawyer, 48, 59-77.

Loderer, C., \& Peyer, U. (2002). Board overlap, seat accumulation, and share prices. European Financial Management, 8, 165-192. http://dx.doi.org/10.1111/1468-036X.00183

Maka, Y., \& Kusnadi, Y. (2005). Size really matters: Further evidence on the negative relationship between board size and firm value. Pacific-Basin Finance Journal, 13, 301-318. http://dx.doi.org/10.1016/j.pacfin.2004.09.002

Mitton, T. (2002), Across-firm analysis of the impact of corporate governance on the East Asian financial crisis. Journal of Financial Economics, 64, 215-241. http://dx.doi.org/10.1016/S0304-405X(02)00076-4

Pearce, J. A., \& S. A. Zahra. (1992). Board composition from a strategic contingency perspective. Journal of Management Studies, 29, 411-438. http://dx.doi.org/10.1111/j.1467-6486.1992.tb00672.x

Pfeffer, J., \& Salancik, R. (1978). The external control of organizations: A resource-dependence perspective. New York: Harper \& Row.

Postma, T., Van Ees, H., \& Sterken, E. (2003). Board composition and firm performance in the Netherlands. Research report, Research Institute SOM (Systems, Organizations, and Management), University of Groningen.

Shleifer, A., \& Vishny, R. W. (1992). Liquidation values and debt capacity: A market quilibrium approach. Journal of Finance, 47, 1343-13661. http://dx.doi.org/10.1111/j.1540-6261.1992.tb04661.x

Stulz, R. (1990). Managerial discretion and optimal financing policies. Journal of Financial Economics, $26,3-271$. http://dx.doi.org/10.1016/0304-405X(90)90011-N

Taymaz E., \& Ozler, S. (2007). Foreign Ownership, Com- petition and Survival Dynamics. Review of Industrial Organization, 31, 23-42. http://dx.doi.org/10.1007/s11151-007-9144-x

Yermack, D. (1996). Higher market valuation of companies with a small board of directors. Journal of Financial Economics, 40, 185-212. http://dx.doi.org/10.1016/0304-405X(95)00844-5

Yurtoglu, B. B. (2000). Ownership, control and performance of Turkish listed firms, Empirica, 27, $193-222$. http://dx.doi.org/10.1023/A:1026557203261 